\title{
Chinese Translation of Modal Verb Shall in Shakespeare's Measure for Measure
}

\author{
Bian Wu \\ Post-doctoral Research Center, Guangdong University of Foreign Studies \\ Guangzhou, Guangdong, China \\ E-mail: wubianxisu@126.com
}

Received: August 21, 2019 Accepted: September 12, 2019 Published: October 8, 2019

doi:10.5296/ijl.v11i5.15589

URL: https://doi.org/10.5296/ijl.v11i5.15589

\begin{abstract}
Modal verbs are a type of verbs which express meanings such as volition, ability, possibility, necessity, etc. In Shakespeare's plays, modal verbs are characterized by their large numbers and rich meanings, with some of their meanings different from their present-day English descendants. For instance, shall has the meaning "order to", besides "intend to", "ought to", "be to". This paper focuses on the differences among the Chinese translations of SHALL in Measure for Measure, by Zhu Shenghao, Liang Shiqiu, Fang Ping, Ying Ruocheng, and Peng Jingxi, its aim being to find out SHALL's exact meanings and appropriate ways to render them in Chinese. The result shows that SHALL in Measure for Measure appears 86 times with 4 different meanings, which are "intend to", "ought to", "order to", "be to". Liang Shiqiu and Peng Jingxi tended to adopt formal equivalence in their translations, and Zhu Shenghao, Fang Ping and Ying Ruocheng tended to adopt functional equivalence in their translations.
\end{abstract}

Keywords: Measure for Measure, Chinese translations, Shall

\section{Introduction}

English historians usually divide English history into three periods, which are Old English period (449-1100), Middle English period (1100-1500), and Modern English period (1500-now), while modern English period can be further divided into Early Modern English period (1500-1700), Late Modern English period (1700-1900) and Present-day English period (1900-now) (Freeborn, 1992; Hogg \& Denison, 2006; Chen, 2000). If language researchers or translators ignore the differences of English in different times, misunderstanding and mistranslation will happen. This paper focuses on the Chinese translations of modal verb SHALL in Shakespeare's Measure for Measure by five translators, 
i.e. Zhu Shenghao, Liang Shiqiu, Fang Ping, Ying Ruocheng, and Peng Jingxi, its aim being to find out SHALL's exact meanings in Shakespeare's time and appropriate ways to render them in Chinese.

\section{Literature Review}

The biggest disagreement on the study of modal verbs in Early Modern English (EME for short) is that the researchers held different views on modal verbs' meanings. Taking SHALL as an example, some researchers (such as Wallis, 1972 etc.) claimed that SHALL had two meanings in EME period, while the others (such as Abbott, 1972; Bolton, 1992 etc.) argued that SHALL had more than two meanings in EME period. In order to solve this problem appropriately, this paper decides to make reference to Oxford English Dictionary (1884-1928/1989, OED for short). The reason for that is OED is the most authoritative language research tool in English world. The lexical meanings in OED are arranged in accordance with historical principle, which can thoroughly present the developing progress of a word's meaning to the dictionary users. This research will take SHALL's meanings in 1500-1700 from OED as the criteria of sense identification. From OED, we found that SHALL has four meanings in EME period, which are "intend to", "oblige to", "order to", and "be to", as shown in Table 1.

Table 1. SHALL's meanings in early modern English

\begin{tabular}{|c|c|c|}
\hline Items & Instances & Researchers \\
\hline $\begin{array}{l}\text { Intend } \\
\text { to }\end{array}$ & We shall, my liege. (H5 4.1.27) & $\begin{array}{l}\left.\text { OED (shall v }{ }^{1} 6\right) \text {; Schmidt (1971, } \\
\text { p. 1040); Patridge (1969, p. 113); } \\
\text { Abbott (1972, p. 224); Bolton } \\
\text { (1992, p. 51); Adamson (2001, p. } \\
\text { 224); Gotti et al. (2002, p. 78); } \\
\text { Nakayasu (2009, p. 209) }\end{array}$ \\
\hline $\begin{array}{l}\text { Oblige } \\
\text { to }\end{array}$ & $\begin{array}{l}\text { The money shall be paid back again with } \\
\text { advantange. (1H4 2.4.403-404) }\end{array}$ & $\begin{array}{l}\left.\text { OED (shall v }{ }^{1} 2 / 3\right) \text {; Schmidt (1971, } \\
\text { p. 1039); Patridge (1969, p. 114); } \\
\text { Abbott (1972, p. 223); Kakietek } \\
\text { (1972, p. 40); Brook (1976, p. } \\
\text { 113); Barber (1976, p. 260); Kytö } \\
\text { (1991, p. 287); Bolton (1992, p. } \\
\text { 54); Ronberg (1992, p. 65); } \\
\text { Adamson (2001, p. 203); Blake } \\
\text { (2002, p. 125); Gotti et al. (2002, } \\
\text { p. 205); Nakayasu (2009, p. 78) }\end{array}$ \\
\hline $\begin{array}{l}\text { Order } \\
\text { to }\end{array}$ & $\begin{array}{l}\text { Thou shalt not from this grove. (MND } \\
2.1 .149)\end{array}$ & $\begin{array}{l}\left.\text { OED (shall v }{ }^{1} 5\right) \text {; Schmidt (1971, } \\
\text { p. 1040); Patridge (1969, P114); } \\
\text { Abbott (1972, p. 225); Ronberg } \\
\text { (1992, p. 67); Gotti et al. (2002, p. } \\
\text { 290); Nakayasu (2009, p. 78) }\end{array}$ \\
\hline
\end{tabular}

Be to When shall we three meet againe? (Mac OED (shall v $\left.{ }^{1} 4 / 8 / 9 / 10\right)$; Schmidt 
1.1.1)

(1971, p. 1039); Patridge (1969, p.

113); Abbott (1972, p. 223);

Kakietek (1972, p. 36); Brook

(1972, p. 113); Barber (1976, p.

256); Onion (1986, p. 247); Kytö

(1991, p. 287); Bolton (1992, p.

51); Ronberg (1992, p. 68);

Rissanen (1999, p. 210); Adamson

(2001, p. 224); Blake (2002, p.

125); Gotti et al. (2002, p. 224);

Nakayasu (2009, p. 78)

\section{Research Design}

\subsection{The Definition of Modal Verbs and Classification of Modality}

This paper defines modal verbs in EME period as a subjective element expressing speaker's linguistic subjectivity. Morphologically, they have tense change; functionally, they are the finite elements of the predicate; semantically, they can express the speaker's assertions to ability, possibility, necessity, obligation, permission, volition etc. And we classified the modal verbs' meanings into three types with reference to Palmer (1965/1987). They are dynamic modality, deontic modality and epistemic modality. Dynamic modality is used to describe a factual situation about the subject of the sentence; deontic modality is used to affect a situation by giving permission or obligation; epistemic modality is used to express the speaker's opinion about a statement.

\subsection{Analytical Framework}

Based on the relations between form and meaning, this paper classifies the translation equivalence into four types, which are "formal and semantic equivalence", "formal mismatch but semantic equivalence", "formal match but semantic non-equivalence", "formal and semantic non-equivalence". Among the above four types, "formal and semantic equivalence" is similar to Nida's (1969, p. 159) "formal equivalence", which emphasizes the absolute correspondence between the translated version and the original version in both form and meaning. While "formal mismatch but semantic equivalence" is similar to Nida's "dynamic equivalence" (1969, p. 159), which emphasizes the influence of translated version on target readers should be comparable to that of original version on source readers.

\subsection{Corpus Selection}

The linguistic data chosen in this paper mainly comes from Shakespeare's Measure for Measure. The reason for choosing this play is that it has possessed many Chinese translated versions, which can provide rich materials for this research to do contrastive studies. Besides, the content of this play is also quite interesting.

Since Shakespeare's plays have different editorial editions, it is better to choose one that is suitable for this study. After the comparative analysis of different versions, we decide to 


\section{I Macrothink}

International Journal of Linguistics

ISSN 1948-5425

2019, Vol. 11, No. 5

choose the Royal Shakespeare Company's Measure for Measure as the master copy. The reason for that is this edition is edited on the basis of First Folio, which is quite closer to the language art of Shakespeare. Beyond that, it has abundant annotations which are quite convenient for users to make reference to.

Up to now, there are seven Chinese translated versions of Measure for Measure in total, i.e. Zhu Shenghao (1994), Ying Ruocheng (1999), Fang Ping (2000), Liang Shiqiu (2001), Peng Jingxi (2012), Qiu Cunzhen (1944), and Peng Fasheng (2016). This research only takes the first five translators' works into consideration. The reason for that is these five translated versions have been widely circulated around China, and they have their own characteristics and influences.

\subsection{The Construction of English-Chinese Parallel Corpus}

As mentioned above, modal verbs occur frequently in Shakespeare's plays, so it is not suitable for researchers to do the data collection and data analysis directly in the paper texts. Therefore, a small parallel corpus of English and Chinese was constructed for data processing. The specific steps are as follows. Firstly, we transformed the paper texts into TXT format; secondly, we employed the software "Super Align" to align the bilingual corpus; thirdly, we made use of "BFSU ParaConc 1.2.2" to retrieve the corpus, as Figure 1 shows.

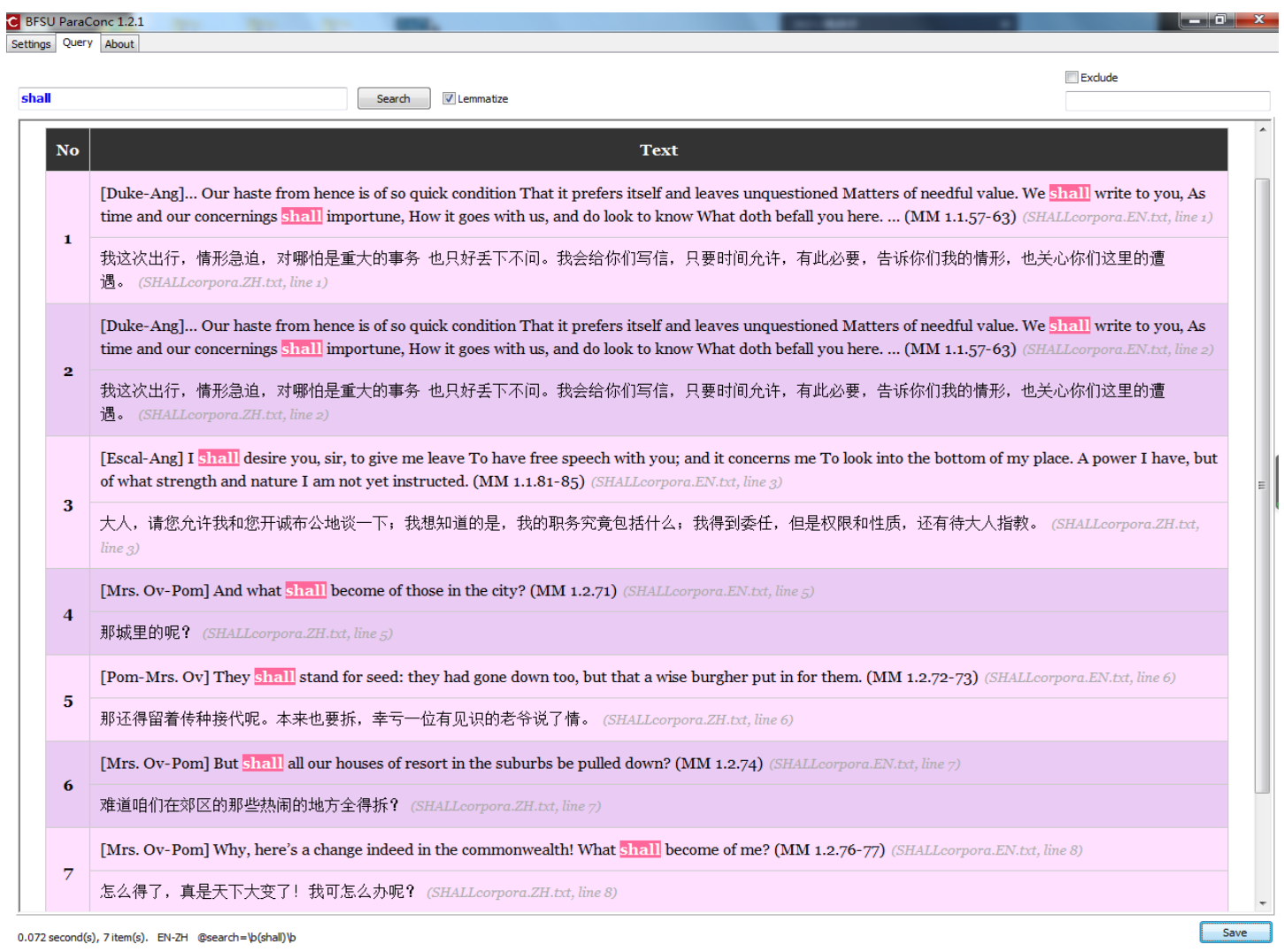

Figure 1. Retrieval example of BFSU ParaConc 1.2.2

\subsection{Research Methodology}

This paper adopts the contrastive method to approach SHALL's translation. Through the 
contrastive study between English and Chinese modal systems, we are attempting to build up an analytical framework for translation analysis. Through the contrastive study among different translated versions, we are trying to find out the shortcomings of the existing versions and put forward views of this research.

\section{Data Analysis}

\subsection{SHALL's Meaning Distribution in Measure for Measure}

Through data retrieval, we found 86 cases of SHALL in Shakespeare's Measure for Measure, and they contained four different meanings, which are "intend to", "oblige to", "order to", "be to". Among these four meanings, "intend to" belongs to dynamic modality; "obliged to" and "order to" belong to deontic modality; "be to" belongs to epistemic modality. As Table 2 shows, epistemic modality occupies the highest ratio (68.6\%), and dynamic modality comes next $(19.8 \%)$, while the deontic modality occupies the lowest ratio (11.6\%).

Table 2. SHALL's meaning distribution in Measure for Measure

\begin{tabular}{|c|c|c|c|c|c|}
\hline Modality & Meaning & Instances & Case & & \\
\hline Dynamic & Intend to & $\begin{array}{l}\text { We shall employ thee in a worthier place. } \\
(M M 5.1 .550-553)\end{array}$ & 17 & 19.8 & 19.8 \\
\hline \multirow{2}{*}{ Deontic } & Oblige to & $\begin{array}{l}\text { What shall be done, sir, with the groaning } \\
\text { Juliet? }(M M 2.2 .16-23)\end{array}$ & 5 & 5.8 & \\
\hline & Order to & $\begin{array}{l}\text { let her appear, And he shall marry her. }(M M \\
2.2 .16-23)\end{array}$ & 5 & 5.8 & 11.6 \\
\hline \multirow[t]{2}{*}{ Epistemic } & Be to & $\begin{array}{l}\text { Come, tell me true, it shall be the better for } \\
\text { you. }(M M 2.1 .175-178)\end{array}$ & 59 & 68.6 & 68.6 \\
\hline & & Tol. & 86 & 100 & 100 \\
\hline
\end{tabular}

4.2 Chinese Translation of SHALL in Measure for Measure

\subsubsection{SHALL Means "Intend to"}

A total of 17 cases occurred in the original text when SHALL was used to indicate "intend to". And there appeared 3 types of translation strategies in 5 Chinese versions, which are "formal and semantic equivalence", "formal mismatch but semantic equivalence", "formal and semantic non-equivalence".

(1) formal and semantic equivalence

[1] DUKE. [...] Thanks, good friend Escalus, for thy much goodness,

There's more behind that is more gratulate.

Thanks, provost, for thy care and secrecy,

We shall employ thee in a worthier place. (MM 5.1.550-553)

英：谢谢你, 狱官, 为了你的操劳和严守机密, 今后要给你更高的官职。

彭: 典狱长, 谢谢你的细心与保密; 本爵要把派你担任更尊贵的职位。

方：多谢了, 你尽心尽力, 以后我还要好好地酬劳你。 
梁: 谢谢你, 狱官, 你辛劳而且机密; 我要以较高的官职叙用你。

朱: 狱官, 因为你的谨慎机密, 我要给你一个好一点的官职。

Example [1] is selected from Act 5 Scene 1. At the end of the trial, the Duke promised to give the provost a better position in the near future. In the sentence "we shall employ thee in a worthier place", "shall" means "intend to". It is a typical dynamic modality. Ying Ruocheng, Peng Jingxi, Fang Ping, Liang Shiqiu, and Zhu Shenghao all translated it into Chinese modal verb “要”. “要” means "intend to". It corresponds to the original text both formally and semantically.

(2) formal mismatch but semantic equivalence

[2] MESSENGER. My lord hath sent you this note, and by me this further charge, that you swerve not from the smallest article of it, neither in time, matter, or other circumstance. Good morrow, for, as I take it, it is almost day.

PROVOST. I shall obey him. (MM 4.2.92-95)

英: 我一定遵命。

彭: 我一定遵命。

方：我一定服从他命令。

梁: 我一定遵命。

朱: 我一定服从他的命令。

Example [2] is selected from Act 4 Scene 2. A messenger sent a letter to the provost. The letter was written by Angelo. He ordered the provost to execute Claudius in the morning no matter what will happen. In the sentence "I shall obey him", "shall" means "intend to". Ying Ruocheng, Peng Jingxi, Fang Ping, Liang Shiqiu, and Zhu Shenghao all translated it into Chinese adverb “一定”. “一定” means “intend to”. It corresponds to the original text semantically, but not formally.

[3] ANGELO. Well, I beseech you, let it be proclaimed betimes i'th'morn. I'll call you at your house. Give notice to such men of sort and suit as are to meet him.

ESCALUS. I shall, sir. Fare you well. (MM 4.4.11-13)

英：谨遵大人之命。再见。

彭: 遵命, 大人。再会了。

方: 尊命, 大人。告辞了。

梁: 是的, 先生: 再会。

朱: 是, 大人, 下官失陪了。

Example [3] is selected from Act 4 Scene 4. Angelo and Escalus were preparing for the Duke's returning to the city. In the sentence "I shall, sire, Fare you well", "I shall" means "I 
will”. Ying Ruocheng, Peng Jingxi, Fang Ping, Liang Shiqiu and Zhu Shenghao translated it into Chinese verbs or verbal phrases, such as “遵命”, “尊命”, “是的”, “是”, “谨遵大人之 命”. All these forms correspond to the original text semantically, but not formally.

(3) formal and semantic non-equivalence

[4] DUKE. [...] Him I'll desire

To meet me at the consecrated fount,

A league below the city, and from thence,

By cold gradation and well-balanced form,

We shall proceed with Angelo. (MM 4.3.75-85)

彭: [...] 我希望他在城南三哩处的圣泉与我会合; 然后再从那里, 井然有序地遵照正 式礼仪, 和安其洛一起出发。

Example [4] is selected from Act 4 Scene 3. When the Duke learned of Angelo's treachery, he decided to expose his misdeeds step by step. He asked Angelo to meet him at the consecrated fount, a league below the city, and in that place he will hold the trial. In the sentence "we shall proceed with Angelo", "we shall" means "I will". Peng Jingxi didn't translate it out, which belongs to willful omission.

\subsubsection{SHALL Means "Oblige to"}

A total of 5 cases occurred in the original text when SHALL was used to indicate "oblige to". And there appeared 2 types of translation strategies in 5 Chinese versions, which are "formal and semantic equivalence", "formal mismatch but semantic equivalence".

(1) formal and semantic equivalence

[5] ANGELO. Plainly conceive I love you.

ISABELLA. My brother did love Juliet,

And you tell me that he shall die for't.

ANGELO. He shall not, Isabel, if you give me love. (MM 2.4.148-151)

英: 我的兄弟也爱过朱丽叶特, 但是您说他为此必须一死。

彭: 舍弟也爱朱莉, 而您却告诉我, 他必须为此而死。

方: 我兄弟同样地爱朱丽叶, 你却对我说, 为了他这爱, 就得死。

梁：我的弟弟爱了朱丽叶; 你说他要因此而处死。

朱: 我的弟弟爱朱丽叶, 你却对我说他必须因此受死。

Example [5] is selected from Act 2 Scene 4. Angelo confessed to Isabella if she can accept his love, Claudius would be saved from death. Isabella strongly disagreed. In the sentence "My brother did love Juliet, and you tell me that he shall die for't", "shall" means "oblige to". It is a typical deontic modality. Ying Ruocheng, Peng Jingxi, Fang Ping, Liang Shiqiu and Zhu Shenghao all translated it into Chinese modal verbs “必须”, “得”, and “要”, which all 
indicated "oblige to". It corresponds to the original text both formally and semantically.

[6] PROVOST. I crave your honour's pardon.

What shall be done, sir, with the groaning Juliet?

She's very near her hour.

ANGELO. Dispose of her

To some more fitter place, and that with speed. (MM 2.2.16-23)

英：还有那辗转呻吟的朱丽叶特应该如何处置？她已经到了临产的时刻。

彭：请问要怎么处理呻吟的朱莉? 她快要临盆了。

方: 我还得请示, 大人, 朱丽叶快临产了, 日夜在呻吟, 该怎么发落她?

梁: 那呻吟床蓐的朱丽叶该怎么处置呢? 她就要临盆了。

朱: 请大人恕卑职失言, 卑职还要请问大人, 朱丽叶快要分娩了, 她现在正在呻吟枕藦, 我们应当把她怎样处置才好?

Example [6] is selected from Act 2 Scene 2. Juliet was ready to give birth. The provost consulted Angelo on what kind of arrangement should be made for her. In the sentence "what shall be done, sire, with the groaning Juliet", "shall" means "obliged to". Ying Ruocheng, Peng Jingxi, Fang Ping, Liang Shiqiu, and Zhu Shenghao translated it into Chinese modal verbs “应该”, “应当”, “要”, “该”, which all indicate “oblige to”. The above Chinese forms correspond to the original text both formally and semantically.

(2) formal mismatch but semantic equivalence

[7] DUKE. O, sir, you must, and therefore I beseech you

Look forward on the journey you shall go.

BARNARDINE. I swear I will not die today for any man's persuasion. (MM 4.3.41-43)

英：可是，先生，你必须同意。我因此请你心情坦然地走上你的旅途。

方: 哎哟, 无法挽救了, 你死期就是在今天, 所以说, 请赶紧做好准备, 上路吧。

朱：嗳哟, 这是没有法想的, 你今天一定要死, 所以我劝你还是准备走上你的旅途吧。

Example [7] is selected from Act 4 Scene 3. The Duke persuaded Barnardine to prepare for death. In the sentence "I beseech you look forward on the journey you shall go", "shall" means "oblige to". Ying Ruocheng, Fang Ping, and Zhu Shenghao all changed the syntactic structure of the original text, but the translated versions still contained the meaning of "oblige to".

\subsubsection{SHALL Means "Order to"}

A total of 5 cases occurred in the original text when SHALL was used to indicate "order to". And there appeared 2 types of translation strategies in 5 Chinese versions, which are "formal and semantic equivalence", "formal mismatch but semantic equivalence". 
(1) formal and semantic equivalence

[8] SECOND GENTLEMAN. Amen.

LUCIO. Thou concludest like the sanctimonious pirate, that went to sea with the Ten Commandments, but scraped one out of the table.

SECOND GENTLEMAN. 'Thou shalt not steal'? (MM 1.2.4-7)

彭: 不可偷窃?

方: 是 “不可偷盗” 那一诫吗?

梁：“你不可愉窃”?

朱: 是 “不可偷盗” 那一诫吗?

Example [8] is selected from Act 1 Scene 2. Lucio commented on the second gentleman's conversation like a pirate going to sea with Ten Commandments. In the sentence "Thou shalt not steal", "thou shalt not" means "I order you not to". It is a typical deontic modality. Peng Jingxi, Fang Ping, Liang Shiqiu and Zhu Shenghao all translated it into Chinese modal verb “不可”. “不可” means “not allow to". It corresponds to the original text both formally and semantically.

(2) formal mismatch but semantic equivalence

[9] LUCIO. [...] Good my lord, do not recompense me in making me a cuckold.

DUKE. Upon mine honour, thou shalt marry her.

Thy slanders I forgive, and therewithal

Remit thy other forfeits. [...] (MM 5.1.538-544)

彭：我以荣誉保证，你非娶她不可。[…]

梁: 你非娶她不可。[…]

方: 我说话算数, 你给我去跟那女的结婚。[…]

Example [9] is selected from Act 5 Scene 1. When the Duke heard Lucio had made a prostitute pregnant, he ordered him to marry her in no time. In the sentence "Upon mine honour, thou shalt marry her", "thou shalt" means "I order you to". Peng Jingxi and Liang Shiqiu translated it into Chinese phrase “非...不可”. Fang Ping changed the assertive mood of the original sentence into imperative mood. Both the phrase “非...不可” and imperative mood carried the meaning of "have to". They correspond to the original text semantically, but not formally.

\subsubsection{SHALL Means "Be to"}

A total of 59 cases occurred in the original text when SHALL was used to indicate "be to". And there appeared 2 types of translation strategies in 5 Chinese versions, which are "formal and semantic equivalence", "formal mismatch but semantic equivalence". 


\section{Macrothink}

(1) formal and semantic equivalence

[10] PROVOST. Ay, my good lord, a very virtuous maid, And to be shortly of a sisterhood, If not already.

ANGELO. Well, let her be admitted. See you the fornicatress be removed. Let her have needful but not lavish means. There shall be order for't. (MM 2.2.27-33)

彭: [...] 给她必要的资源, 但不可浪费。会有命令给你。

方: […] 给她把必需品准备好, 可不能太讲究。那指令会随即签发的。

梁: [...] 你去把那淫妇搬走: 随后会有命令的。

朱: [...] 给她一切必需的东西, 但不必过奢; 我就会签下命令来。

Example [10] is selected from Act 2 Scene 2. Juliet was ready to give birth. Angelo asked the provost to give her the necessities for the delivery. In the sentence "There shall be order for't", "shall" means "be to". It is a typical epistemic modality. Peng Jingxi, Fang Ping, Liang Shiqiu, and Zhu Shenghao translated it into Chinese modal verb “会”, “会” means "be to". It corresponds to the original text both formally and semantically.

(2) formal mismatch but semantic equivalence

[11] DUKE. [...] Go call at Flavius's house,

And tell him where I stay. Give the like notice

To Valentius, Rowland, and to Crassus,

And bid them bring the trumpets to the gate.

But send me Flavius first.

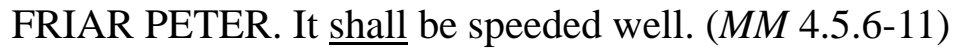

英：我马上去办。

彭: 我这就去。

方：我马上就去办理这些事。

梁: 立刻遵办。

朱: 是, 我马上就去。

Example [11] is selected from Act 4 Scene 5. The Duke asked Friar Peter to inform the ministers and trumpeters to meet him at the city gate. In the sentence "It shall be speeded well", "shall" means "be to". Ying Ruocheng, Peng Jingxi, Fang Ping, Liang Shiqiu, and Zhu Shenghao translated it into Chinese adverbs “马上”, “立刻”, “这就”, which all indicated “be to". They correspond to the original text semantically, but not formally. 
Table 3. SHALL's equivalent types in five translator's Chinese versions

\begin{tabular}{ccrrrrr}
\hline Types & & Zhu & Liang & Fang & Ying & \multicolumn{1}{c}{ Peng } \\
\hline formal and semantic & Tot. & 46 & 48 & 45 & 47 & 52 \\
\cline { 2 - 7 } equivalence & Freq. & $53.5 \%$ & $55.8 \%$ & $52.3 \%$ & $54.7 \%$ & $60.5 \%$ \\
\hline formal mismatch but & Tot. & 39 & 37 & 40 & 39 & 34 \\
\cline { 2 - 7 } semantic equivalence & Freq. & $45.3 \%$ & $45.3 \%$ & $46.5 \%$ & $45.3 \%$ & $39.5 \%$ \\
\hline formal and semantic & Tot. & 1 & 1 & 1 & 0 & 0 \\
\cline { 2 - 7 } non-equivalence & Freq. & $1.2 \%$ & $1.2 \%$ & $1.2 \%$ & $0 \%$ & $0 \%$ \\
\hline
\end{tabular}

As shown in Table 3, Peng's version has the highest ratio of formal and semantic equivalence $(60.5 \%)$, while Fang's version has the highest ration of formal mismatch but semantic equivalence $(46.5 \%)$; in terms of formal and semantic non-equivalence, Zhu, Liang, and Fang's versions have higher ratio (1.2\%), compared with Ying and Peng's versions (0\%). The data above shows that Peng has retained the formal features of the original text the most while Fang has retained fewer such features; and Zhu, Liang, Fang have deviated from the original modal meaning the most while Ying and Peng have deviated the least. Through analysis, the dissertation argues that Peng Jingxi and Liang Shiqiu tended to adopt the strategy of formal equivalence, and Zhu Shenghao, Fang Ping, Ying Ruocheng tended to adopt the strategy of dynamic equivalence in their translation of SHALL.

The reasons for such stylistic differences probably result from the fact that the five translators have totally different translation purposes and strategies. Liang Shiqiu and Peng Jingxi are the typical representatives of "formal equivalence". Liang Shiqiu's purpose in translating Shakespeare is to "arouse readers' interest in the original text" (Liang, 1966, p. 60). He argued that "the translated text should correspond to the original one sentence by sentence" (Ke, 1988, p. 48). Peng Jingxi's translation purpose is to provide script for stage performance and he advocated the strategy of "preserving the original meaning while retaining the form" (Peng, 2004, p. xv; Peng, 2012, p. 5).

Fang Ping, Ying Ruocheng, and Zhu Shenghao are the typical representatives of "dynamic equivalence". Zhu Shenghao's purpose in translating Shakespeare is to popularize Shakespeare's works in China. He advocated that the translated version should "keep the original charm to the maximum extent" (Zhu, 1947). Fang Ping's translation purpose is to arouse readers' interest in the original text ( $\mathrm{Li}, 2010$, p. 256). Ying Ruocheng's translation purpose is "to enable the audiences to get the same impression as those original audiences" (Ying, 1999, p. 9). He claimed that Shakespeare's translators should not adhere rigidly to the original form (Zhang, 2014, p. 69).

\section{Conclusion}

As mentioned above, SHALL possesses four different meanings in Early Modern English, and all of them appeared in Shakespeare's Measure for Measure. Through the contrastive analysis of Zhu Shenghao, Liang Shiqiu, Fang Ping, Ying Ruocheng, and Peng Jingxi's translated versions, we find that modal verb "SHALL" has various correspondent forms in Chinese, which included modal verbs, verbs, adverbs, phrases etc. Beyond that, the above 


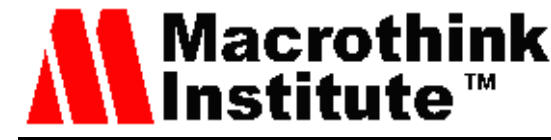

International Journal of Linguistics ISSN 1948-5425

five translators also unfold quite different styles in dealing with SHALL's translation. Generally speaking, Peng Jingxi and Liang Shiqiu tend to adopt "formal equivalence", while Zhu Shenghao, Ying Ruocheng and Fang Ping tend to adopt "functional equivalence". The reason for that lies in the translation purposes and translation principles varied differently from translators to translators.

\section{References}

Abbott, E. A. (1874). A Shakespearian Grammar: An Attempt to Illustrate Some of the Differences between Elizabethan and Modern English (3rd ed.). London \& New York: Macmillan and Company.

Adamson, S., \& et al.. (Eds.) (2001). Reading Shakespeare's Dramatic Language: A Guide. London: Thomson Learning.

Barber, C. (1976). Early Modern English. London: Andre Deutsch.

Bate, J., \& Rumussen, E. (Eds.). (2007/2008). The RSC Shakespeare: The Complete Works. Beijing: Foreign Language Teaching and Research Press.

Blake, N. (2002). A Grammar of Shakespeare's Language. New York: Palgrave.

Bolton, W. F. (1992). Shakespeare's English: Language in the History Plays. Oxford: Basil Blackwell.

Brook, G. (1976). The Language of Shakespeare. London: André Deutsch Limited.

Chen, G. (2000). Guide Reading to "From Old English to Standard English". Foreign Language Teaching and Research, (5), 393-396.

Fang, P. (2000). Measure for Measure. Shi Jiazhuang: Hebei Education Publishing House.

Freeborn, D. (1992). From Old English to Standard English. New York: Palgrave Macmillan.

Gotti, M., \& et al.. (2002). Variation in Central Modals: A Repertoire of Forms and Types of Usage in Middle English and Early Modern English. Bern: Peter Lang AG.

Hogg, R., \& Denison, D. (2006). The History of the English Language. New York: Cambridge University Press.

Johnson, K. (2013). Shakespeare's English: A Practical Linguistic Guide. Edinburgh: Pearson Education Limited.

Kakietek, P. (1972). Modal Verbs in Shakespeare's English. Poznan: Universytet Im. Adama Mickiewicza W Poznaniu.

Ke, F. (1988). Liang Shiqiu's Talk on Shakespeare's Translation. Foreign Language Teaching and Research, (1), 46-51.

Kytö, M. (1991). Variation and Diachrony, with Early American English in Focus. Frankfurt: Peter Lang. 


\section{Macrothink}

International Journal of Linguistics

ISSN 1948-5425

2019, Vol. 11, No. 5

Li, C. (2010). A Research on Chinese Translations of Shakespearean Plays. Tianjin: Tianjin Academy of Social Sciences Press.

Liang, S. (1966). Shakespeare's 400 ${ }^{\text {th }}$ Anniversary: A Collection of Essays. Taipei: National Institute for Compilation and Translation.

Liang, S. (2001). Measure for Measure. Beijing: China Radio Film \& TV Press.

Nakayasu, M. (2009). The Pragmatics of Modals in Shakespeare. Frankfurt: Peter Lang $\mathrm{GmbH}$.

Nida, E. A., \& Taber, C. R. (1969). The Theory and Practice of Translation. Leiden: E. J. Brill.

Onion, C. T., \& Eagleson, R. A. (1986). Shakespeare Glossary. Oxford: Oxford University Press.

Palmer, F. (1965/1987). The English Verb (2nd ed.). Essex: Longman Group UK Limited.

Patridge, A. (1969). Tudor to Augustan English: A study in syntax and style from Caxton to Johnson. Kent: Tonbridge Printers LTD.

Peng, F. (2012). Measure for Measure. Beijing: Foreign Language Teaching and Research Press.

Peng, J. (2004). Perusing Shakespeare: A Collection of Essays. Taipei: National Taipei University Press.

Peng, J. (2012). Measure for Measure. Taipei: Linking Publishing Corporation.

Qiu, C. (1944). Measure for Measure. Chongqing: Shangyang Publishing House.

Rissanen, M. (1999). Syntax. In Roger Lass (Ed.), The Cambridge History of the English Language Volume III 1476-1776. Beijing \& Cambridge: Peking University Press, Cambridge University Press.

Ronberg, G. (1992). A Way With Words: The Language of English Renaissance Literature. New York: Routledge, Chapman and Hall, Inc.

Schmidt, A. (1971). Shakespeare Lexicon and Qutation Dictionary (3rd ed.). New York: Dover Publications.

Simpson, J. A., \& S. C. Edmund. (1884-1928/1989/2002). Oxford English Dictionary (OED). Oxford: Oxford University Press.

Wallis, J. (1653/1972). Grammatica Linguae Anglicanae. London: Longman.

Ying, R. (1999). Measure for Measure. Beijing: China Translation and Publishing Corporation.

Zhang, W. (2014). Theory and Practice of Theatre Translation: A Review of Ying Ruocheng's Theatre Translation. Journal of Guangdong University of Foreign Studies, (2), 68-71. 


\section{Macrothink}

International Journal of Linguistics

ISSN 1948-5425

2019, Vol. 11, No. 5

Zhu, S. (1947). Preface to the complete work of William Shakespeare. In Luo, X. (Ed.), Traduction (2009). Beijing: The Commercial Press.

Zhu, S. (1994). Measure for Measure. Beijing: People's Literature Publishing House.

\section{Copyrights}

Copyright for this article is retained by the author(s), with first publication rights granted to the journal.

This is an open-access article distributed under the terms and conditions of the Creative Commons Attribution license (http://creativecommons.org/licenses/by/4.0/) 